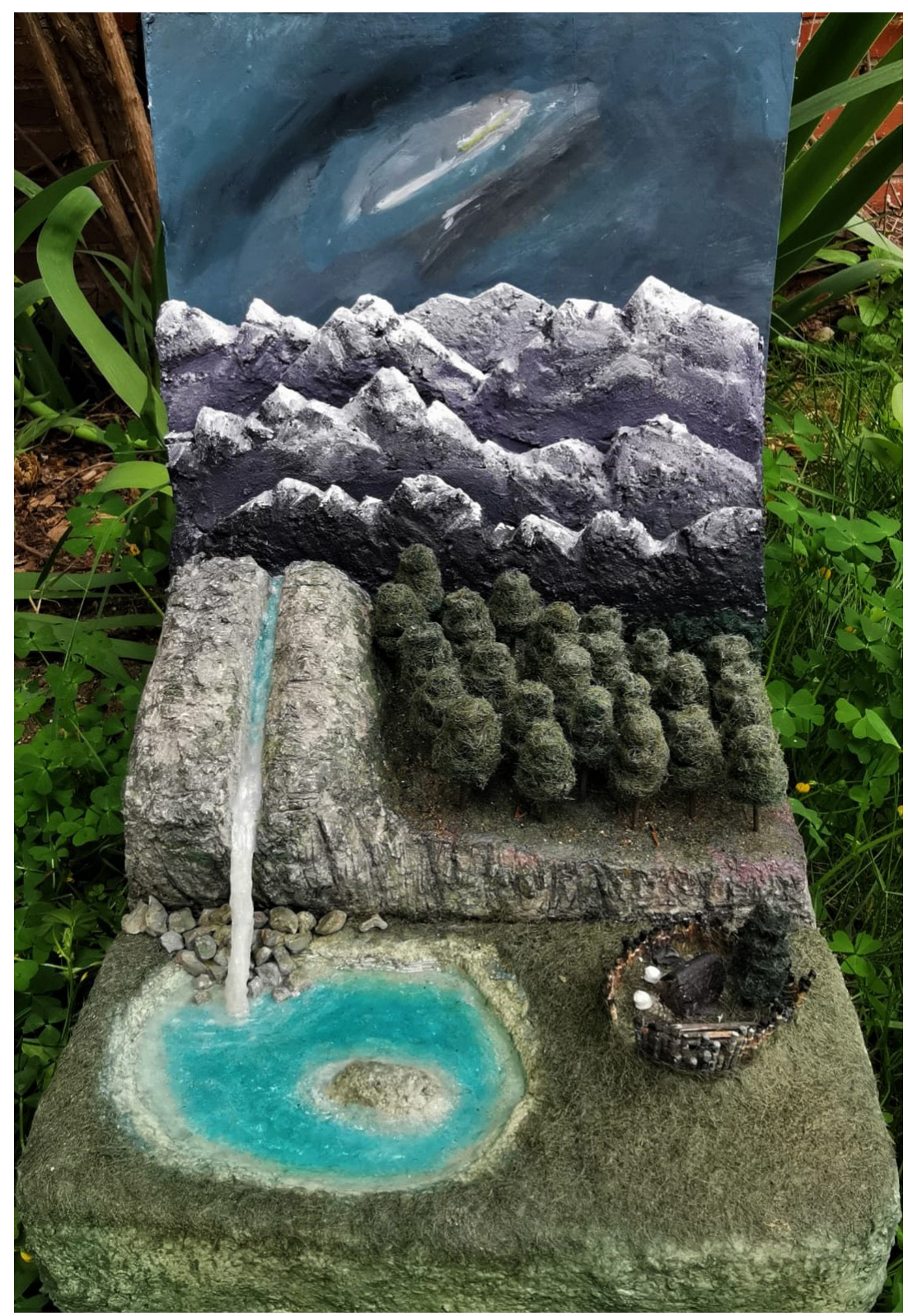

\title{
Maqueta Valle de Arán
}

\section{Reflexión}

La tarea escolar de mi hija nos transporta a la expansión ampliada de la montaña. Dejamos a nuestras espaldas el limitado perímetro doméstico y nos adentramos, como gigantes diosas creadoras, en un espacio donde todo es posible.

Realizar una maqueta es hacer magia. El recinto de la reclusión se vuelve inmenso y se abre a paisajes de la imaginación transformados en delicada verdad.

\section{Autoras}

Ana Iribas Rudín

Socia de AFIA y FEAPA

Magíster universitario en Arteterapia, Universidad Complutense de Madrid

Alaia Loiseau Iribas

10 años

Arteterapia: papeles de arteterapia y educación artística para la integración social.

Monográfico: Las miradas del arte y el arteterapia en tiempos de la Covid19. ISSN-e: 1988-8309 https://dx.doi.org/10.5209/arte.75894 